\title{
Biodegradation of synthetic dyes: a mycoremediation approach for degradation/decolourization of textile dyes and effluents
}

\begin{abstract}
Present review highlights the role of fungi in biodegradation/decolourization of textile dyes and effluents. Though, fungi and bacteria both are the principal decomposer of xenobiotics in the environment but fungi are superior to bacteria in dyes degradation/ decolourization due to their superiority in the production of dyes degrading enzymes and as absorbent. The present study focused on the achievements and advancement on the fungal degradation/decolourization of textiles dyes and effluents by the application of potent fungal strains. The biodegradation through fungi or myco-remediation of textile dyes and effluents using potential fungi is comparatively cheap and environmentally safe process, to decompose or mineralize the hardly or less degrading compounds of synthetic dyes. Fungi play an important role to degrade/decolourize the synthetic dyes through enzymes as well as by the absorption, adsorption and accumulation of colourants from the effluents.
\end{abstract}

Keywords: biodegradation, myco-remediation, accumulation, textile dyes, effluents, fungi, fungal enzymes, peroxidase, ligninase
Volume 3 Issue 5 - 2017

\author{
Lokendra Singh \\ Department of Botany, University of Delhi, India
}

Correspondence: Lokendra Singh, Department of Botany, D.S.B. Campus, Kumaun University, Nainital-263 002, Uttarakhand, India, Email mycologistlokendra@gmail.com

Received: June 01, 2017 | Published: August 29, 2017
Abbreviations: TOC, total organic carbon; BOD, biological oxygen demand; COD, chemical oxygen demand; PAHs, polycyclic aromatic hydrocarbons; RBBR, remazol brilliant blue R; LiP, lignin peroxidase; MnP, manganese-dependent peroxidase; Dyp, dye degrading peroxidase

\section{Introduction}

Rapid industrialization, developmental processes or modernization has given rise some unwanted toxic elements into the atmosphere. These elements are accumulated in the biosphere up to toxic level and creating problems in the environment, by destroying the natural ecosystem. For example, a measurable quantity of synthetic dyes as textile discharges or effluents from these industries are coming out directly to natural water bodies (after the dying processes). These hazardous effluents are being settled to water bodies (directly and indirectly) that finally contaminating to the water and soil. Textile dyes and effluents from the dying processes has adverse impacts on the water quality in terms of total organic carbon (TOC), biological oxygen demand (BOD), chemical oxygen demand (COD), colour, $\mathrm{pH}$ and presence of recalcitrant synthetic compounds, such as azodyes and heavy metals. ${ }^{1,2}$ The water polluted by the textile industry discharges has received an increased attention for several decades, to set up the strategies to solve the present problem. ${ }^{3}$ Different types of synthetic dyes and pigments are used worldwide for the coloring processes in textile and allied industries. Inefficiency in dying process, poor handling of spent effluent and insufficient treatment of wastes from dyestuff industries lead to dye contamination in soil and natural water bodies. Untreated textile effluents may contain a large number of heavy metals like, $\mathrm{Cd}, \mathrm{Cr}, \mathrm{Co}, \mathrm{Cu}, \mathrm{Hg}, \mathrm{Ni}, \mathrm{Mg}, \mathrm{Fe}$ and $\mathrm{Mn}$ that are highly toxic, mutagenic and carcinogenic. The pollutants, aggravated by the presence of free chlorine and toxic heavy metals, cause rapid depletion of dissolved oxygen, leading to "Oxygen Sag" in the receiving water. ${ }^{4,5}$ The textile industries constitute a vast majority of the dyes which are discharged in the wastewaters. Over 100,000 commercial dyes exist and more than $7 \times 10^{5}$ tons of dyestuff is produced annually, of which $1-1.5 \times 10^{5}$ tons is released into the wastewaters. These synthetic dyes and their effluents are recalcitrant to microbial degradation and causing problems in the usual biological degradation. Among the synthetic dyes, azo dyes, characterized by the presence of one or more azo groups $(-\mathrm{N}=\mathrm{N}-)$, and anthrax-quinonic dyes represent the largest and most versatile group of dyes. ${ }^{6-9}$ The synthetic dyes with azo group (e.g. monoazo, diazo, triazo and polyazo), represent the largest class of organic colorants i.e. account for $60-70 \%$ of the total used synthetic dyes. Moreover, dyes have become a health hazard as many of them and/or their breakdown products have been found to be toxic and potentially carcinogenic. . $^{4,10,11}$

Microorganisms are able to degrade synthetic dyes to non-coloured compounds or even mineralize them completely under certain environmental conditions Bioremediation is one of the most effective and successful cleaning techniques for the removal of toxicants from polluted environments. ${ }^{12-14}$ The microbial degradation of textile dyes has been reported using different microorganisms including bacteria, yeasts and filamentous fungi., ${ }^{3,15,16}$ The biodegradation studies on the dyes degradation by using fungi Phanerochaete chrysosporium, Bjerkandera adusta, Trametes versicolor, Phlebia radiata and Pleurotus spp. have been shown the production of enzyme laccase that was found highly related to lignin and dyes degradation. ${ }^{17-21}$ These fungi are found potent much to degrade a broad spectrum of structurally diverse group of dyes. Heinfling et al. ${ }^{18}$ reported that Bjerkandera adusta and T. versicolor are able to remove $95 \%$ of HRB 8 dye within four days. Due to the fungi oxidative mechanisms it is possible to avoid the formation of hazardous anilines, formed by reductive cleavage of the azo dyes, by other microorganisms such as bacteria. ${ }^{22}$ The interest in the fungal degradation/decolourization of textile dyes is mainly due to the expression of some non-specific extracellular enzymes, as the ligninolytic peroxidases, that have been implicated in 
the degradation of synthetic dyes. ${ }^{23,24}$ White-rot fungi produce several enzymes that have been related to their ability to degrade natural polymers, such as lignin and cellulose, but can also degrade different synthetic chemicals, usually recalcitrant to biodegradation. ${ }^{25,26}$ The promising results obtained with this ligninolytic fungus, lead to the study of the potentialities of other species of ligninolytic basidiomycetes. The role of fungi in the wastewater treatment has been proved them to be suitable and effective for dyes degradation/ decolourization and the removal of colourants from the textile effluents. Dyes and pigments are being removed by these fungi either in living or dead form through bio-sorption, bio-degradation, bioaccumulation and enzymatic mineralization, using lignin peroxidase, manganese peroxidase, manganese independent peroxidase and laccase. ${ }^{27-30}$ Fungi has been shifted the research interest for the bio-treatment of wastewater ingredients such as metals, inorganic nutrients and organic compounds. Physico-chemical treatment processes, such as coagulation, precipitation, filtration, adsorption, photolysis and oxidation with hydrogen peroxide or ozone, can generate a large volume of sludge and usually require the addition of other environmental hazardous chemical additives. ${ }^{31-33}$ Biological treatment technologies are attractive alternatives to the traditional physicochemical methods, as they are low-cost, environmental friendly and can selective to provide a complete degradation of organic pollutants without collateral destruction of either the site's flora or fauna. ${ }^{2,15,34}$ Therefore, as better alternatives, biological processes are getting more and more attention since it does not produce harmful byproducts as well as large quantity of sludge. ${ }^{35}$ Fungi are not only used to decolourize/degrade the hazardous dyes (i.e. azo, anthraquinone, heterocyclic, triphenylmethane and polymeric dyes) but also used to have some beneficial products from the wide range of waste materials, by their bio-transformation. ${ }^{36-38}$ Investigations on the topic have been emphasized the biodegradation processes. In present review I have tried to explore the research endeavors and achievements as well as advancements in mycoremediation processes targeting the application of fungi in degradation/decolourization of textile dyes and other hazardous effluents.

Table I Phenoloxidase activity and categorization of Fungi. ${ }^{42}$

\section{Fungi and dye degradation}

Fungi and bacteria, both are the principal degraders of organic matters, but fungi are better known for the purpose due to their superiority in the enzyme production. Traditionally, fungi have been classified as white-, brown-, or soft-rot fungi on the basis of technical decay and descriptions, ${ }^{39}$ regardless of their taxonomic position. Because the enzyme systems and metabolic pathways involved in the breakdown of carbohydrates and lignins probably are truly distinct in these fungi, rather than just modified in one or a few specific enzyme activities, decay type is of significant taxonomic importance. One important physiological characteristic of decay fungi in culture is the production of extracellular enzymes phenoloxidases and peroxidases. Certain fungi produce brown diffusion zones in agar plates when supplemented with $0.5 \%(\mathrm{w} / \mathrm{v})$ Gallic or tannic acid, as a result of oxidation of the respective phenolic acid by extra-or intracellular phenoloxidases. Bavendamm ${ }^{40}$ suggested that the presence of phenoloxidases in white-rot fungi is directly correlated with the abilities of these fungi to the decomposition of lignin. Davidson et al. ${ }^{41}$ was the first to extend this method to 210 species of wood decaying fungi. Of all tested white-rot fungi, 96\% were positive on gallic acid agar, tannic acid agar, or on the both media. Kaarik ${ }^{36}$ tested 173 wood-decaying species on the plates supplemented with 28 substances and found wide variations in the reactions of given strains to specific phenolic compounds. The basidiomycetous fungus Phanerochaete chrysosporium has an unusual degradative capability and termed as "white rot fungus" because of its ability to degrade lignin, a randomly linked phenylpropane-based polymeric component of wood. The fungus possesses great potential for its commercial use in bioremediation of dyes and lignin-cellulosic materials present in textile effluents. The fungus has become a model example for its uses in mycoremediation and for its biotechnological application in biodegradation. Freitage et al. ${ }^{42}$ screened 170 strains of white-, brown-, and soft-rot decay fungi and non-decaying xylophilophilous fungi for phenoloxidase activity with the polymeric dye Poly-478, to relate dye decolourization to know ligninolytic activity and the presence of phenoloxidase and peroxydases. On the basis of their growth, these fungi were classified into fast, slow and little growing fungi (Table 1).

\footnotetext{
White-Rot Fungi

Fast Bjerkandera adusta, Ceriporiopsis rivulosa, C. subvermispora, Diplomitoporus lindbladii, Hyphoderma puberum, P. chrysosporium,

growing P. sordida, P. gigantea, Phlebia concentrica, Ph. subserialis, Ph. tremellosa, Ph. albida, Ph. merismoides, Ph. rufa, Pycnoporus

fungi $\quad$ sanguineus, Trametes versicolor, T. villosa, T. hirsuta, Irpex lacteus.

Slow Acanthophysium lividocoerulem, Ganoderma oregonense, Gymnopilus sp., Heterobasidion annosum, Lentinula edodes,

growing Mycoacia uda, Peniophora sp., Peniophora pseudo-pini, Perenniporia subacida, Phellinus weirii, Phlebia rufa, Pleurotus ostreatus,

fungi Schizophyllum commune, Sistotrema brinkmannii, Stereum hirsutum, Stereum sanguinolentum, Trametes versicolor, Trichaptum abietinum, Trichaptum biforme, Tyromyces sp.

Little Acanthophysium lividocoeruleum, Armillaria mellea, Bondarzewia montana, Cystostereum pini-canadense, Dichostereum growing pallescens, Heterobasidion annosum, Pholiota adiposa, Pleuroflammula puberula, Polyporus varius, Schizophyllum commune, fungi Sistotrema octosporum, S. brinkmannii, Stereum gausapatum, Trichaptum biforme.

Wilkolazka et al. ${ }^{43}$ studied the potential of 115 fungal strains for the degradation/decolourization of structurally different azo and anthraquinonic dyes. They reported Abortiporus biennis, Bjerkandera fumosa, Cerrena unicolor, Clitocybula dusenii, Dichomitus albiodofuscus, Diplomitiporus crustulinus, Flammulina velutipes, Gonoderma lucidum, G. applanatum, Heterobasidion annosum, Keuhneromyces mutabilis, Lentinus edodes, Nematoloma

frowardii, Panus tigrinus, Perenniporia subacida, Phanerochaete chrysosporium, Phlebia radiata, Pholiota glutinosa, Pleurotus pulmonarius, Pycnoporus coccineus, Stropharia rugosoannulata, Tremetes sanguinea, T. versicolor, and also Agrocybe cylidracea, Geotrichum sp. Gloeophyllum odoratum, Pestalotia sp., Coprinus micaceus, Fomtopsis pinicola, as potential fungal strains to degrade/ decolourize, the tested dyes.
} 
Mechanism of dye degradation: Biodegradation has at least three step; a minor change in an organic molecule leaving the main structure still intact, fragmentation of a complex organic molecule in such a way that the fragments could be reassembled to yield the original structure, and complete mineralization i.e. transformation of organic molecules to mineral forms, including carbon dioxide or methane, plus inorganic forms of other elements that might have contained the original structures. ${ }^{2,7}$ Ferrell et al. ${ }^{44}$ compared the colour removal efficiency of lyophilized fungal culture with lignin peroxidase, both the lyophilized culture and enzyme decoloured the dye. A well-defined lignin-degrading enzyme system, consisting of lignin peroxidase, $\mathrm{Mn}$ (II)-dependent peroxidase (MnP) and glyoxal-oxidase, was found to be involved in the dye degradation. Adsorption of dyes to the microbial cell surface is the primary mechanism of decolourization. Absorption was found to be important mechanism that contributes to the decolourization process, possibility to initial transformation of the dye degradation. ${ }^{45}$ Microscopic examinations showed that the fungal spores, instead of the fungal hyphae were actually absorbing the dye. A hydrophobic-hydrophillic interaction between the fungus and the dye might contribute to the absorption phenomenon. The dye colour decreased, when either the enzyme or the cell mass concentrations were increased indicating that the dye degradation occurred both by enzymatic action as well as adsorption to the cell mass. The concerted action of both led to greater degradation than single.

White-rot fungi are unique among eukaryotes in their ability to cleave carbon-carbon bonds in polycyclic aromatic hydrocarbons (PAHs), for the biological degradation of these compounds. The breakdown of most organo-pollutants by ligninolytic fungi is closely linked with ligninolytic metabolism and generally thought that lignin degrading enzymes (whose normal function is lignin degradation) also catalyse the highly nonspecific xenobiotics oxidation that is the characteristic of these fungi. The lignin-degrading system of whiterot fungi includes a family of lignin peroxidases, or ligninases as they are commonly known for the initial oxidative depolymerization of lignin..$^{17,46}$ Spadaro et al. ${ }^{23}$ reported that fungus P. chrysosporium is capable to mineralize a variety of toxic dyes and other hazardous aromatic rings compounds, due to the liginolytic activities of the fungi. Several mechanisms have recently been elucidated for the fungi to degrade the synthetic dyes and other organo-pollutants. ${ }^{43,47}$ The first step in the degradation of many dyes by white-rot fungi often involves the formation of highly reactive free radical intermediates. These free radicals are formed any time; one electron is removed or added to the ground state of a chemical. Such free radicals are very reactive and rapidly give up or abstract an electron from another chemical. This free radical reaction often occurs as chains in which many different radicals are generated subsequent to the formation of the initial radical species. The free radical process provides some basis for the non specific nature of white-rot fungi. The free radical reactions catalyzed by the peroxidases from white-rot fungi also appear to be involved in the degradation of a variety of pollutants. ${ }^{26,45}$ Paszczynski et al. ${ }^{19}$ reported the involvement of veratryl alcohol during the degradation of azo compounds. Veratryl alcohol stimulated azo dye oxidation by ligninase, acting as a third substrate (with $\mathrm{H}_{2} \mathrm{O}_{2}$ and the azo dye) in the cycle back the enzyme to its native state.

The dye degradation or dye removal process mediated by fungi may be categorized into biosorption, bioaccumulation and biodegradation (Figure 1A-1D). Adsorption of the dyes to the microbial cell surface is the primary mechanism of decolourization..$^{35,45,48}$ Wong et al. ${ }^{49}$ reported the adsorption of Acid green 27, Acid violet 7 and Indigo carmine dyes on living and dead mycelia of Trametes versicolor. Biosorption is a metabolically independent process which involves the binding of solutes to the fungal biomass and thus dye decolourization can occur by either living or dead fungal biomass. ${ }^{50}$ The dead fungal biomass contains a natural polysachharide chitin and its derivative chitosan in their cell walls which has a unique molecular structure with a high affinity for many classes of dyes. Hence, fungal biomass can be used as efficient absorbent for synthetic dyes. Bioaccumulation is an energy and metabolically dependant process, where actively growing cells accumulate the pollutants inside their cytoplasm (Figure 1A-1D). Biodegradation is also an energy intensive and metabolically dependant process, where the complex dye molecules are broken down into simpler molecules through the action of certain enzymes. Decolourization of dye is related to the presence of extracellular peroxidases, particularly manganese peroxidases. ${ }^{27}$

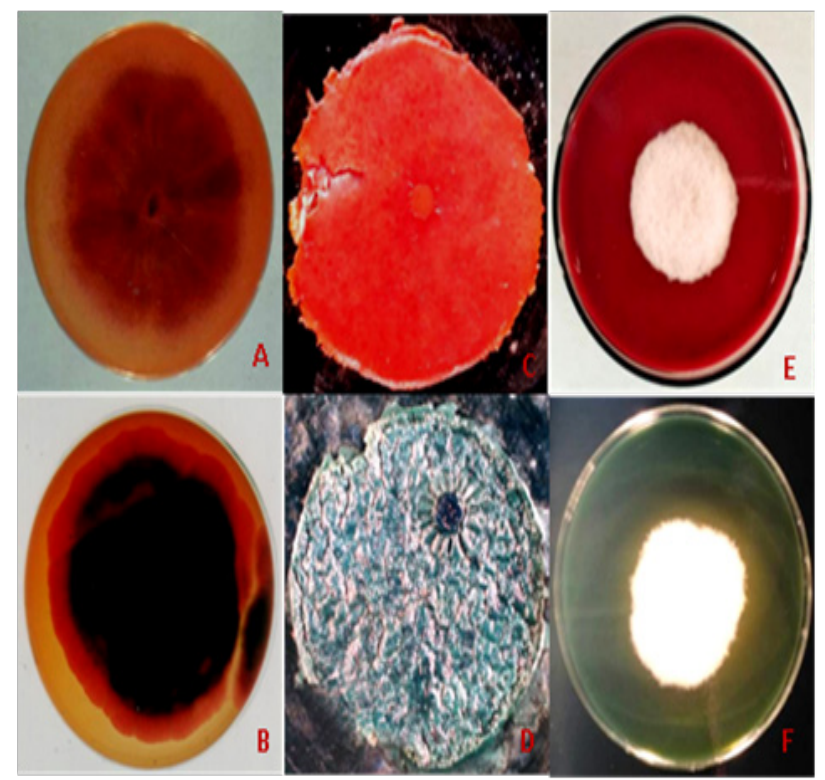

Figure I Accumulation/absorption of synthetic dyes by the fungal strains and effect of dyes on the fungal growth during the screening of dye degradation/ decolourization

i. Accumulation of dye Acid Red by Aspergillus sp. (A) and Trichoderma harzianum (B) in solid medium.

ii. Absorption of dye Congo red and Basic Blue by the living mycelium of Aspergillus flavus (C) and Trichoderma harzianum (D), respectively.

iii. Fusarium sp. showing growth inhibition (E) during the degradation/decolourization of dye Congo red compared to the growth in PDA medium (F).

Although dye molecules display high structural diversity, they are only degraded by a few enzymes that share common mechanistic features as they all catalyze redox reactions and, exhibit relatively wide substrate specificities. The most important dye degrading enzymes are: azoreductases, laccases and peroxidases. Azoreductases are oxidoreductases, which are particularly effective in the degradation of azo dyes through reduction of the azo linkage, the chromophoric group of azo dyes. ${ }^{51}$ These enzymes have a great potential in various biotechnological processes mainly due to their high non-specific oxidation capacity, the lack of requirement for cofactors, and the use of the readily available molecular oxygen as an electron acceptor. These include the detoxification of industrial effluents, mostly from the paper and pulp, textile and petrochemical industries, and bioremediation to 
clean up herbicides, pesticides and certain explosives in soil. ${ }^{15,52-54}$ Fungal biomasses walls are composed of macromolecules (chitin, chitosan, glucan, lipid, phospholipides), which contain carboxyl groups $(\mathrm{RCOOH})$, amino groups $\left(\mathrm{R}_{2} \mathrm{NH}, \mathrm{R}-\mathrm{NH}_{2}\right)$, phosphates, lipids, melanin, sulphates $\left(\mathrm{R}_{-} \mathrm{OSO}_{3}-\right)$ and hydroxides $(\mathrm{OH}-)^{55-57}$ These functional groups are metals sorption sites that play an active role in dye and organo-pollutants degradation. ${ }^{58-60}$ Fungi are also used for metal removal generally through the adsorption, chemisorptions (ion exchange), complexation, coordination, chelation, physical adsorption and micro-precipitation. ${ }^{55}$ Metals removal by fungi from various raw effluents (gold mining effluent, tanning effluent, swine water, polluted lake waters) are sometimes completely or partially, depend on the metal and potentiality of fungus involved. When metals are removed by ionic exchange, they generally replace $\mathrm{K}^{+}, \mathrm{Mg}^{2+}, \mathrm{Ca}^{2+}$ and $\mathrm{H}^{+}$contained in biomasses. ${ }^{61,62}$ To increase the removal capacities of fungi some physicochemical treatments such as soda or acidic treatments, insertion of functional groupings, heat treatment are essential. ${ }^{63,64}$ Kapoor et al. ${ }^{57}$ also demonstrated that the soda treated biomass of $\mathrm{A}$. niger, removed $\mathrm{Cd}^{2+}, \mathrm{Cu}^{2+}$ and $\mathrm{Pb}^{2+}$ with a higher rate of absorption. Yong et al ${ }^{65}$ suggested that the binding of dyes to the fungal hyphae, physical adsorption and enzymatic degradation by extracellular and intracellular enzymes, is a major mechanism for the colour removal by the fungi.

Fungal enzymes and their role in dye degradation: Bumpus et al. ${ }^{26}$ and Barr et al. ${ }^{46}$ reported that Lentinus edodes (Shiitake), a most popular edible mushroom, produces high amounts of manganes peroxidase (MnP, EC 1.11.1.14). The extracellular production of ligninolytic enzymes by L. Edodes mycelium growing on a solid medium decolorized several dyes such as Poly-478 and Remazol Brilliant Blue R (RBBR). Enzymes such as lignin peroxidase (LiP), manganese-dependent peroxidase (MnP) and laccase, all of which are involved in lignin degradation, have been reported to decolourize the synthetic dyes. ${ }^{28} \mathrm{Kim}$ et al. ${ }^{66}$ demonstrated the presence of $\mathrm{H}_{2} \mathrm{O}_{2}$ dependent enzyme activity to declourize the dye Brilliant Blue $\mathrm{R}$ by the fungus Pleurotus ostreatus. Buswell et al. ${ }^{67}$ reported that the production of the extracellular ligninolytic enzymes is strongly affected by the nature and amount of the nutrients, especially nitrogen (N) and microelements, in the growth substrate. The basidiomycetous fungus Ganodermaa lucidum has been found positive for the removal of Rhodamine-B and Sandolan rhodine dyes. Kim et al. ${ }^{29}$ purified the novel dye degrading peroxidase (Dyp) from the fungus Geotrichum candidum Dec 1 that was found responsible for the dye-decolourization, of 21 types of dyes; particular anthroquinone dyes. Swamy et al. ${ }^{30}$ reported the presence of laccase and manganese peroxidase (MnP), during the decolourization of the azo dye (Amaranth), by the fungus Trametes versicolor. The higher percentages of dyes degradation with the presence of laccase produced by $\mathrm{T}$. versicolor and $\mathrm{P}$. ostreatus were also detected by some workers. ${ }^{20,68,69}$ The identification of two hydroxylated metabolites from the degradation of the most degraded dye, allowed the proposition of a metabolic pathway. White-rot fungi are well known for the production of enzymes for dye degradation as commercial level. ${ }^{33}$ White-rot fungus, Thelephora sp. was characterized for ligninolytic activity for the dye decolourization/ degradation. Bio-degradation/decolourization of several textile dyes including Congo red, Bromophenol blue, Acid red, Direct green by the fungi Aspergillus flavus and Trichoderma harzianum has been reported. ${ }^{6,7,16}$

Future Perspectives: Based on the investigations, it is clear that within the microbial diversity, fungi are much important for bio- degradation process of hazardous dyes and effluents. Further, investigations on mycoremediation have also been shown an inhibition in decolourizing fungal strain compared to their growth in a normal medium (Figure $1 \mathrm{E} \& 1 \mathrm{~F}$ ) that might be a reason to get a lower percentage of dye degradation/decolourization after using of potential fungal strains for the same. Inhibition in fungal growth during the dye degradation/decolourization against some specific dye compounds clearly indicates the inefficiency of used fungal strain, might be due to toxicity of dye that suppresses the production of enzymes as well as mycelial growth. Applications of molecular tools and technology to identify genes encoding enzymes in potential fungal strains may be helpful in synthetic dye degradation. ${ }^{48}$ With the help of genetic engineering, genetically modified strains the efficiency of dye degradation/decolurization through fungi may be enhance. Connection among the researchers and policy makers should be come onto the same forum to find out a cheap and environmentally safe large scale treatment process for the industrial effluents. Promotion and set up of interdisciplinary research including chemistry, biochemical and environmental engineering along with microbiology may have success for a permanent biological dye effluent treatment process on a commercial scale, to save and sustain the natural environment from toxic wastes. Proper degradation/decolourization of coloured wastewater from textile industries is major environmental concern. Amongst different chemical, physical and biological treatment methods, the biotechnological approaches based on fungi, are the most effective and environmental friendly methods. Optimization of the culture media in carbon sources or nutrients and mediators molecules is very important to obtain a good output of pollutants degradations.

\section{Conclusion}

Scientific developments are considered as key factors for the progress of both developed and developing countries, but unfortunately, most of the industries do not have proper waste treatment facilities or arrangement, and releasing a large quantity of effluents. A definitive solution for colourants problem of textile effluents would provide a marked advantage for the industrial sector. The success of a microbial process for colour removal from the effluent depends on the utilization of microorganisms that effectively decolourize synthetic dyes of different chemical structures. The fungal degradation/ decolourization of textile dyes has been demonstrated mainly in the laboratory studies. The fungal utilization in dye decolourization is still under investigation to assess the information's on process implementation. The results obtained mainly from the laboratory tests depend on specific growth medium and optimization (addition of co-substrate, nutrients, mediator molecules, physical parameters optimization) and a good handling of fungal strains or biomasses. Therefore, essential works on the topic are still in the laboratories or less at commercial scale to solve the problem of colourants in effluents through mycoremediation. The degradation/decolourization and mineralization of recalcitrant dyes and organo-chlorinated compounds are effective by certain fungi. With regard to fungi, which contribute to effluents degradation either by dead mycelia or with enzymes, there is need to design them for the purpose. Commonly dyes removal treatments do not adequately eliminate the azo dyes from the effluent waters of textile mills and dyestuff industries. In order to develop suitable technology to degrade/decolourize synthetic dyes discharged in the effluent and to convert them into beneficial products simultaneously, a well-planned scientifically acceptable technology is needed. The waste fungal biomass from fermentation 
industry is also a good absorbent that used as bio-sorption for biological effluent treatment in dyes and textile sectors. Enzymatic processes are particularly sought for the treatment of dye-containing effluents, mainly because of their specificity and relatively ease of engineering towards improved robustness; enzymes only "attack" the dye molecules, while valuable dyeing additives or fibers are kept intact and can potentially be re-used. Likewise, new recycling technologies will allow a huge reduction in water consumption in the textile finishing industry. One of the most important factors, which have a great impact on the setting of a proper bioremediation plant for textile wastewater, is the effluent characteristics. Majority of the researches concerning the fungi for mycoremediation of textile wastewaters have been focused the potentiality of fungi in dyes degradation/decolourization while the limitation of these fungi against dye compounds yet haven't been examined properly.

\section{Acknowledgements}

Author is thankful to Head, Department of Botany, University of Delhi, Delhi providing necessary facilities during the laboratory work. I am also thankful to Mr. Harsh Kumar Chauhan and Hardesh Kumar, DSB Campus, Kumuan University, Nainital for their help during the manuscript preparation.

\section{Conflict of interest}

The author declares no conflict of interest.

\section{References}

1. Banat IM, Nigam P, Singh D, Microbial decolorization of textile-dye-containing effluents: a review. Biores Technol. 1996;58:217227.

2. Akan JC, Abdulrahman FI, Ayodele JT, et al. Impact of tannery and textile effluent on the chemical characteristics of Challawa River, Kano State, Nigeria. Aust J Basic Appl Sci. 2009;3(3):1933-1947.

3. Robinson T, McMullan G, Marchant R, et al. Remediation of dyes in textile effluent: a critical review on current treatment technologies with a proposed alternative. Bioresour Technol. 2001;77(3):274-255.

4. Delclos KB, Tarpley WG, Miller EC, et al. 4-Aminoazobenzene and $\mathrm{N}, \mathrm{N}$-dimethyl-4-aminoazobenzene as equipotent hepatic carcinogens in male $\mathrm{C} 57 \mathrm{BL} / 6 \mathrm{XC} 3 \mathrm{H} / \mathrm{He} \mathrm{F}_{1}$ mice and characterization of $\mathrm{N}$-(deoxyguanosine-8-yl)-4-aminoazobenzene as the major persistent hepatic DNA-bound dye in these mice. Cancer Res. 1984;44(6):2540-2550.

5. O'Neil C, Hawkes FR, Hawkes DL, et al. Colour in textile effluents-sources, measurement, discharge consents and simulation: a review. $J$ Chem Technol Biotechnol. 1999;74(11):1009-1018.

6. Singh L, Singh VP. Microbial degradation and decolourization of dyes in semi-solid medium by the fungus-Trichoderma harzianum. Environ. We Int J Sci Tech. 2010;5(3):147-153.

7. Singh L, Singh VP. Biodegradation of textiles dyes, Bromophenol blue and congo red by fungus-Aspergillus flavus. Environ. We Int J Sci Tech. 2010;5(4):235-242.

8. Shah MP. Microbe-mediated degradation of synthetic dyes in wastewater. In: Singh SN editor. Microbial Degradation of Synthetic Dyes in Wastewaters. Environmental science and engineering, Switzerland: Springer International Publishing; 2015. p. 205-241.

9. Singh L, Singh VP. Textile dyes degradation: A microbial approach for biodegradation of pollutants. In: Singh SN, editor. Microbial Degradation of Synthetic dyes in Waste waters. Environmental science and engineering, Switzerland: Springer International Publishing; 2015. p. 187-204.
10. Vander Zee FP, Villaverde S. Combined anaerobic-aerobic treatment of azo dyes-a short review of bioreactor studies. Water Res. 2005;39(8):1425-1440.

11. Singh L, Singh VP. Decolourization of Azo (Acid red) and Anthraquinonic (Basic blue) Dyes by the Fungus Aspergillus flavus. Int J Biomed Engine Cli Sci. 2017;3(1):1-5.

12. Singh L. Bio-degradation of hazardous dyes: A microbial approach for pollutants degradation. Oaks. 2011;7:82-83.

13. Kumar CG, Mongolla P, Basha A, et al. Decolourization and biotransformation of triphenylmethane dye, methyl violet, by Aspergillus sp., isolated from Ladakh, India. J Microbiol Biotechnol. 2011;21(3):267-273.

14. Khan R, Bhawana P, Fulekar MH. Microbial decolorization and degradation of synthetic dyes: a review. Rev Environ Sci Biotechnol. 2013;12(1):75-97.

15. Rodríguez Couto S, Toca Herrera JL. Industrial and biotechnological applications of laccases: a review. Biotechnol Adv. 2006;24(5):500-513.

16. Singh L, Singh VP. Microbial decolourization of textile dyes by the fungus Trichoderma harzianum. J Pure and Appl Microbiol. 2012;6(4):1829-1833.

17. Hammel KE, Gai WZ, Green B, et al. Oxidative degradation of phenanthrene by the ligninolytic fungus Phanerochaete chrysosporium. Appl Environ Microbiol. 1992;58(6):1832-1838.

18. Heinfling A, Bergbauer M, Szewzyk U. Biodegradation of azo and phthalocyanine dyes by Trametes versicolour and Bjerkandera adusta. Appl Microbiol Biotechnol. 1997;48(2):261-266.

19. Paszczynski A, Crawford RL. Degradation of azo compounds by ligninase from Phanerocheate chrysosporium: involvement of veratry alcohol. Biochem Biophys Res Commun. 1991;178:1056-1063.

20. Podgornik H, Grgic I, Perdih A. Decolorization rate of dyes using lignin peroxidases of Phanerochaete chrysosporium. Chemosphere. 1999;38:1353-1359.

21. Singh VP, Singh L, Singh I, et al. Microbial Degradation of Hazardous Dyes. In: Mukerji KG, et al. editors. Current Concepts in Botany. New Delhi, India: IK International Publishing House Pvt Ltd; 2006. p. 273-285.

22. Chung KT, Stevens SE. Decolorization of azo dyes by environmental microorganisms and helminthes. Environ Toxicol Chem. 1993; 12(11):2121-2132.

23. Spadaro JT, Gold MH, Renganathan V. Degradation of azo dyes by the lignin-degrading fungus Phanerochaete chrysosporium. Appl Environ Microbiol. 1992;58(8):2397-2401.

24. Ollikka P, Harjunpää T, Palmu K, et al. Oxidation of Crocein Orange $\mathrm{G}$ by lignin peroxidase isoenzymes. Kinetics and effect of $\mathrm{H}_{2} \mathrm{O}_{2}$. Appl Biochem Biotechnol. 1998;75(2-3):307-321.

25. Field JA, De Jong E, Feijoo Costa G, et al. Screening for ligninolytic fungi applicable to the degradation of xenobiotics. TiBtech. 1993;14:44 49.

26. Bumpus JA, Tien M, Wright D, et al. Oxidation of persistent environmental pollutants by white rot fungus. Science. 1985;228(4706):1434 1436.

27. Gold MH, Glenn JK, Alic M. Use of polymeric dyes in lignin biodegration assays. Methods Enzym. 1998;161:74-78.

28. Vyas BR, Molitoris HP. Involvement of an extracellular $\mathrm{H}_{2} \mathrm{O}_{2}$-dependent ligninolytic activity of the white-rot fungus Pleurotus ostrus in the decolorization of remazol brilliant blue R. Appl Environ Microbiol. 1995;61(11):3919-3927. 
29. Kim SJ, Shoda M. Purification and characterization of a novel peroxidase from Geotrichum candidum Dec. 1 involved in decolorization of dyes. Appl Environ Microbiol. 1999;65(3):1029-1035.

30. Swamy J, Ramsay JA. Effect of $\mathrm{Mn}^{2+}$ and $\mathrm{NH}^{4+}$ concentration on laccase and manganese peroxidase production and Amaranth decoloration by Trametes versicolor. Appl Microbiol Biotechnol. 1999;51:391-396.

31. Pointing SB, Vrijmoed LLP. Decolorization of azo and triphenylmethane dyes by Pycnoporus sanguineus producing laccase as the sole phenoloxidase. World J Microbiol Biotechnol. 2000;16(3):317-318.

32. Coulibaly L, Agathos SN. Transformation kinetics of mixed polymeric substrates under transitory conditions by Aspergillus niger. Afr J Biotechnol. 2003;2(11):438-443.

33. Wesenberg D, Kyriakides I, Agathos SN. White-rot fungi and their enzymes for the treatment of industrial dye effluents. Biotechnol Adv 2003;22(1-2):161-187.

34. Husain Q. Potential applications of the oxidoreductive enzymes in the decolorization and detoxification of textile and other synthetic dyes from polluted water: a review. Crit Rev Biotechnol. 2006;26(4):201-221.

35. Kaushik P, Malik A. Mycoremediation of synthetic dyes: An insight into the mechanism, process optimization and reactor design. In: Singh SN editor. Microbial Degradation of Synthetic Dyes in Wastewaters. Environmental Science and Engineering, Switzerland: Springer International Publishing; 2015. p. 1-25.

36. Kaarik A. The identification of the mycelia of wood-decaying fung by their oxidation reactions with phenolic compounds. Stud For Suec. 1965;31:1-80.

37. Kirby N, Marchant R, McMullan G. Decolorisation of synthetic textile dyes by Phebia tremellosa. FEMS Microbiol Lett. 2000;188(1):93-96.

38. Singh L. Isolation and characterization of fungal strains for bio-decomposition of plant wastes. $108^{\text {th }}$ General Meeting of Boston, Massachusetts, USA: American Society for Microbiology (ASM); 2008.

39. Nilsson T. Defining fungal decay types-final proposal. International research group on wood preservation, Document IRG/WP/1355, Stockholm, Sweden; 1988.

40. Bavendamm W. Uber das vorkommen und den nachweis von oxydasen bei holzzerstorenden pilzen. Z Pflanzenkr Pflanzenschutz. 1928;38:257276.

41. Davidson RW, Campbell WA, Blaisdell DJ. Differentiation of wood-decaying fungi by their reactions on gallic or tannic acid medium. J Agric Res. 1938;57:683-695.

42. Freitage M, Morrell JJ. Decolorization of the polymeric dye poly R-478 by wood-inhabiting fungi. Can J Microbiol. 1992;38:811-822.

43. Wilkolazka AJ, Kochnanska RJ, Malarczy KE, et al. Fungi and their ability to decolorize azo and anthraquinonic dyes. Enzyme Microbial Technol. 2002;30:566-572.

44. Farrell RL, Murtagh KE, Tien M, Physical and enzymatic properties of lignin peroxidase isoenzymes from Phanerocheate chrysosporium. Enzym Microbial Technol. 1989;11:322-328.

45. Knapp JS, Newby PS, Reece LP. Decolorization of dyes by wood-roting basidiomycete fungi. Enzyme Microbial Technol. 1995;17:664-668.

46. Barr DP, Aust SD. Mechanism white-rot fungi use to degrade pollutants. Environ Sci Technol. 1994;28(2):78-87.

47. Call H, Mucke I. Mini review: history, overview and applications of mediated lignolytic systems, especially laccase-mediator-systems (Lignozym-Process). J Biotechnol. 1997;53:163-202.
48. Singh L. Microbial degradation of hazardous dyes: A fungal approach. Delhi, India: University of Delhi; 2003.

49. Wong YX, Yu J. Laccase catalyzed decolorization of synthetic dyes. Wat Res. 1999;3:3512-3520.

50. Srinivasan A, Viraraghavan T. Decolourization of dye wastewaters by biosorbents: a review. J Environ Manage. 2010;91(10):1915-1929.

51. Rodríguez Couto S. Dye removal by immobilised fungi. Biotechnol Adv. 2009;27:227-235.

52. Morozova OV, Shumakovich GP, Gorbacheva MA, et al. "Blue" laccases. Biochemistry. 2007;72(10):1136-1150.

53. Haritash AK, Kaushik CP. Biodegradation aspects of polycyclic aromatic hydrocarbons (PAHs): a review. J Hazard Mater. 2009;169(1-3):1-15.

54. Mikolasch A, Schauer F. Fungal laccases as tools for the synthesis of new hybrid molecules and biomaterials. Appl Microbiol Biotechnol. 2009;82(4):605-624.

55. Kapoor A, Viraraghavan T. Removal of heavy metals from aqueous solution using immobilized fungal biomass in continuous mode. Wat Res. 1998;32:1968-1977.

56. Fogarty RV, Tobin JM. Fungal melanins and their interactions with metals. Enzyme Microb Technol. 1996;19(4):311-317.

57. Kapoor A, Viraraghavan T, Cullimore DR. Removal of heavy metals using the fungus Aspergillus niger. Biores Technol. 1999;70:95-104.

58. Mullen MD, Wolf DC, Beveridge TJ, et al. Sorption of heavy metals by soil fungi Aspergillus niger and Mucor rouxii. Soil Biol Biochem. 1992;24:129-135.

59. McHale AP, McHale S. Microbial biosorption of metals. Potential in the treatment of metal pollution. Biotechnol Adv. 1994;12(4):647-652.

60. Tereshina VM, Marin AP, Kosyakov NV, et al. Different metal sorption capacities of cell wall polysaccharides of Aspergillus niger. Appl Biochem Microbiol. 1999;35:389-392.

61. Zhou JL. Zn biosorption by Rhizopus arrhizus and other fungi. Appl Microbiol Biotechnol. 1999;51(5):686-693.

62. Gomes NCM, Figueira MM, Camargos ERS, et al. Cyano-metal complexes uptake by Aspergillus niger. Biotechnol Lett. 1999;21:487-490.

63. Yin PH, Yu QM, Ling Z. Biosorption removal of cadmium from aqueous solution by using pretreated fungal biomass cultured from starch wastewater. Wat Res. 1999;33:1960-1963.

64. Yan GY, Viraraghavan T. Effect of pretreatment on the biosorption of heavy metals on Mucor rouxii. Water SA. 2000;26:119-123.

65. Yong L, Yu JT. Ligninase-catalysed decolourization of synthetie dyes. Water Res. 1997;31:1187-1193.

66. Kim SJ, Ishikawa K, Hirai M, et al. Characteristic of a newly isolated fungus, Geotrichum candidum Dec 1, which decolorizes various dyes. $J$ Ferment Bioeng. 1996;79:601-607.

67. Buswell JA, Cai YJ, Chang ST. Effect of nutrient N and manganese on manganese peroxidase and laccasse production by Lentinula (Lentinus) edodes. FEMS Microbiol Lett. 1995;128(1):81-88.

68. Faryal R, Hameed A. Isolation and characterization of various fungal strains from textile effluent for their use in bioremediation. Pak J Bot. 2005;37(4):1003-1008.

69. Huang CP, Huang CP. Application of Aspergillus oryzae and Rhizopus oryzae. Wat Res. 1996;30:1985-1990. 